\title{
Effect of dietary supplementation of Bacillus subtilis on haematological and immunological parameters of Catla catla (Hamilton)
}

\author{
Rajesh Kumar • Subhas C. Mukherjee • Ritesh Ranjan • \\ T. Vani $\cdot$ Rajeev K. Brahmachari $\cdot$ Sukanta K. Nayak
}

Received: 14 August 2014/Accepted: 23 January 2015/Published online: 30 January 2015

(c) Springer International Publishing Switzerland 2015

\begin{abstract}
Effect of dietary supplementation of a Gram-positive, aerobic, probiotic bacterium Bacillus subtilis on the immunohaematological indices during pre- and post-challenge in Indian major carp, catla (Catla catla), was studied. The B. subtilis was administered orally at four different doses $1.0 \times 10^{6}\left(\mathrm{~T}_{1}\right), 1.0 \times 10^{7}\left(\mathrm{~T}_{2}\right), 1.0 \times 10^{8}\left(\mathrm{~T}_{3}\right)$, and $1.0 \times 10^{9}\left(\mathrm{~T}_{4}\right) \mathrm{cfu} \mathrm{g}^{-1}$ feed to $C$. catla for 90 days. The positive control $\left(\mathrm{C}_{\mathrm{p}}\right)$ and negative control $\left(\mathrm{C}_{\mathrm{n}}\right)$ were fed with feed without $B$. subtilis for the same period. On the 60th day, blood and serum were sampled to determine various haematological and serum parameters. Fish were challenged intraperitoneally with Aeromonas hydrophila after 60 days in all the treatment groups and $C_{p}$, while the $C_{n}$ was challenged with phosphatebuffered saline (PBS, pH 7.2) only. Dietary supplementation of B. subtilis leads to the rise of various immunological and haematological parameters in catla during the pre- and postchallenge. During pre-challenge, the highest TEC $\left(1.30 \pm 0.02 \times 10^{6}\right.$ cells mm $\left.^{-3}\right)$, haemoglobin $(7.43 \pm 0.25 \mathrm{~g} \%)$, total serum protein $\left(3.89 \pm 0.08 \mathrm{~g} \mathrm{dL}^{-1}\right)$, and serum
\end{abstract}

R. Kumar $(\bowtie) \cdot$ S. C. Mukherjee · R. Ranjan · R. K. Brahmachari · S. K. Nayak

Aquatic Animal Health Management Division, Central Institute of Fisheries Education (CIFE),

Mumbai 400 061, India

e-mail: rajeshfishco@yahoo.co.uk

R. Kumar

Aquaculture Production and Environment Division, Central Institute of Freshwater Aquaculture, Bhubaneswar 751 002, Odisha, India

R. Ranjan

Mariculture Division, VRC of CMFRI, Visakhapatnam 530 003, Andhra Pradesh, India

T. Vani

Inland Aquaculture Division, CIFE, Mumbai 400 061, India

R. K. Brahmachari

Department of Fish Microbiology, College of Fisheries, Dholi, Muzaffarpur 843 121, Bihar, India

S. K. Nayak

Department of Biotechnology, North Orissa University, Baripada, Odisha, India 
lysozyme activity $\left(8.39 \pm 0.01 \mu \mathrm{g} \mathrm{ml}^{-1}\right)$ were recorded in fishes fed feed containing $B$. subtilis at $1 \times 10^{9} \mathrm{cfu} / \mathrm{g}$ feed $\left(\mathrm{T}_{4}\right)$. The highest survival percentage $(86.33 \%)$ was also observed in $\mathrm{T}_{4}$ group. The significantly increased survival percentage $(P<0.05)$ of $B$. subtilis-treated groups in comparison with control group $\left(\mathrm{C}_{\mathrm{p}}\right)$ suggests that dietary supplementation of this probiotic bacterium can protect catla from A. hydrophila infection by enhancing innate immunity.

Keywords Bacillus subtilis · Aeromonas hydrophila $\cdot$ Catla catla $\cdot$ Immunity · Respiratory burst activity - Total erythrocyte count

\section{Introduction}

The intensification of aquaculture has led to a high number of disease outbreaks with an increasing range of pathogens. Traditional disease control strategies employ antibiotics and chemical disinfectants, but these are no longer recommended practices due to the emergence of bacterial resistance and concerns over environmental impacts. Therefore, the use of various types of immunostimulants/probiotics has been advocated as an alternative method for the prevention and control of diseases in aquaculture (Irianto and Austin 2002; Kumar et al. 2006; Merrifield et al. 2010a; Weissmann 2010; Ranjan et al. 2012). Probiotics, defined as beneficial live micro-organisms when administered to a host at an effective dose, provide a potential alternative strategy for reducing disease outbreaks. Since Metchnikoff laid the foundation of probiotics research through modulation of gut microbiota (Weissmann 2010), this field has progressed gradually and now been established in a wide range of species. In aquaculture, probiotics use is gaining importance as potential alternatives to antibiotics for disease control, growth promoters, immune enhancer and also for improving water quality (Kumar et al. 2006; Merrifield et al. 2010b; Nayak 2010; Dimitroglou et al. 2011). Recently, the advantages of using probiotics in fish aquaculture were reviewed by Qi et al. 2009 and Nayak 2010.

Currently, several probiotic species are available, and the most common types include Lactobacillus, Bacillus, Enterococcus, Clostridium, Shewanella, Leuconostoc, Lactococcus, Carnobacterium, Aeromonas, and several other species (Nayak 2010; Kim et al. 2010; Salinas et al. 2005). Among them, Bacillus strains have been indisputably effective in terms of growth performance, survival, immunity, and disease resistance of different fish species (EL-Dakar et al. 2007; Nayak et al. 2007; Bagheri et al. 2008; Aly et al. 2008; Kumar et al. 2008; Merrifield et al. 2010a; Diaz-Rosales et al. 2009). However, there is no universal class of probiotic bacterium and therefore, the suitability and effectiveness of a probiotic strain need to be established with respect to individual fish species.

Catla catla, one of the major freshwater cultured fish species in India, is also native to Nepal, Bangladesh, Myanmar, and Pakistan and already been introduced in several other countries as exotic species (FAO 2006). The fish is often reported to suffer from infectious diseases at all stages of growth (Wimalawickrama and Pathiratne 2005). Therefore, in the present study, we aimed to assess the efficacy of Bacillus subtilis, as a suitable probiotic strain to protect catla from Aeromonas hydrophila by enhancing various haematological and immunological parameters during pre- and post-challenge. 


\section{Materials and methods}

\section{Fish}

Indian major carp, $C$. catla with an average weight of $13.0 \pm 2.0 \mathrm{~g}$ were procured from a commercial carp farm (Palghar, Maharashtra, India) and maintained in the wet laboratory of Central Institute of Fisheries Education (CIFE), Mumbai. The fingerlings were first diptreated with potassium permanganate $(50 \mathrm{ppm})$ and then carefully transferred to the concrete tank and acclimatized under aerated conditions.

\section{Probiotic strain}

Bacillus subtilis, a gastrointestinal bacterium, isolated from Cirrhinus mrigala was obtained from the Central Institute of Freshwater Aquaculture, Bhubaneswar, India. The bacterium was reconfirmed biochemically and maintained in nutrient agar slant at $4{ }^{\circ} \mathrm{C}$ for further use. The mass culture of this strain was done by growing it in nutrient broth at $30{ }^{\circ} \mathrm{C}$ for $24 \mathrm{~h}$ in a shaker incubator. The culture was centrifuged at $10,000 \mathrm{~g}$ for $20 \mathrm{~min}$ at $4{ }^{\circ} \mathrm{C}$, and the bacterial pellet was re-suspended in phosphate-buffered saline (PBS; pH 7.2). The suspension was similarly washed and re-centrifuged thrice and then quantified by the spread plate technique. Purified and quantified bacteria were kept at $4{ }^{\circ} \mathrm{C}$ in suspended form and were used for feed preparation as required.

\section{Experimental diet}

Experimental diet was prepared by thoroughly mixing the different ingredients such as rice bran $(30 \%)$, oil cake (30\%), fish meal (20\%), wheat flour (14\%), sunflower oil (3\%), vitamin and mineral mixture $(2 \%)$, and CMC (1\%) followed by steaming for 20 min. Probiotic strain (B. subtilis) at specified concentration was mixed thoroughly in cooled conditions, and then, pellets were made by a hand pelletizer. Five types of diets were prepared, that is, $\mathrm{C}$ (control; without probiotic), $\mathrm{T}_{1}\left(1.0 \times 10^{6} \mathrm{cfu} \mathrm{g}^{-1}\right), \mathrm{T}_{2}\left(1 \times 10^{7}\right.$ cfu $\left.\mathrm{g}^{-1}\right), \mathrm{T}_{3}\left(1.0 \times 10^{8} \mathrm{cfu} \mathrm{g}^{-1}\right)$, and $\mathrm{T}_{4}\left(1 \times 10^{9} \mathrm{cfu} \mathrm{g}^{-1}\right)$. The prepared experimental diet was sun-dried and stored in refrigerator at $4{ }^{\circ} \mathrm{C}$. The concentrations of $B$. subtilis in the feed were determined by spread plate technique (nutrient agar, incubated at $30{ }^{\circ} \mathrm{C}$ for $24 \mathrm{~h}$ ). The final concentration of probiotic strain was expressed as number of colonyforming unit per gram $\left(\mathrm{cfu} \mathrm{g}^{-1}\right)$ feed. Experimental diet was prepared every week to retain high percentage of viable probiotic bacteria.

\section{Experimental design}

Two hundred and seventy fingerlings were randomly distributed in six experimental groups in rectangular plastic tanks of 1001 capacity with aeration in triplicate, following a complete randomized design in the wet laboratory of CIFE, Mumbai. The experiment was conducted for a period of 90 days, and the whole experiment was divided into two parts, that is, pre-challenge study conducted for 60 days and post-challenge study for another 30 day. During pre-challenge study, fish were fed different diet containing B. subtilis $\left(\mathrm{T}_{1}-\right.$ $\mathrm{T}_{4}$ ), while on 60th day, fish were challenged intraperitoneally with virulent pathogen Aeromonas hydrophila $\left(10^{6} \mathrm{cfu} / \mathrm{ml}\right)$ and the mortality was observed for another 30 days during which the same experimental diet was continued. Two control groups (positive 
control; $\mathrm{C}_{\mathrm{p}}$ and negative control; $\left.\mathrm{C}_{\mathrm{n}}\right)$ were also maintained. In the positive control $\left(\mathrm{C}_{\mathrm{p}}\right)$, fish were fed feed without $B$. subtilis (control diet) and challenged with A. hydrophila, while in negative control $\left(C_{n}\right)$, fish were also fed control diet and challenged with phosphatebuffered saline (PBS) only.

Blood sample was collected from each treatment group on 60th day post-feeding and on 90th day post-feeding (i.e. 30 days after challenge) from the survived catla to study the various different immunohaematological changes during pre- and post-challenge. Blood was drawn from the caudal peduncle using a sterile 1-ml syringe and then collected in Eppendorf tubes coated with $20 \mu \mathrm{l}$ of $2.7 \%$ EDTA solution for studying various haematological parameters. Similarly, blood was collected without anticoagulant for serum and immunological parameters studies. After collection, blood samples were kept at room temperature for $1 \mathrm{~h}$ and then centrifuged at 2,500g for $10 \mathrm{~min}$. Serum was then collected and kept at $-20{ }^{\circ} \mathrm{C}$ till further use.

Aeromonas hydrophila and challenge study

A. hydrophila O:18 was received from the Aquatic Animal Health and Management Division, Central Institute of Fisheries Education (CIFE), Mumbai. The isolate was verified and kept in nutrient agar slant at $4{ }^{\circ} \mathrm{C}$ for further use. A. hydrophila was inoculated in nutrient broth (Himedia Ltd, Mumbai, India) and incubated at $30{ }^{\circ} \mathrm{C}$ for $24 \mathrm{~h}$. The culture was centrifuged at 3,000 $\mathrm{g}$ for $10 \mathrm{~min}$. The supernatant was discarded, and the pellet was re-suspended in sterile phosphate-buffered saline (PBS, $\mathrm{pH}$ 7.4). Then, the bacterial number was calculated by measuring optical density (OD) in a spectrophotometer and also confirmed by plate count method. The final bacterial concentration was adjusted to $1 \times 10^{6} \mathrm{cfu} / \mathrm{ml}$ by serial dilution.

All the treated groups including control $\left(\mathrm{C}_{\mathrm{p}}\right)$ were intraperitoneally challenged with $200 \mu \mathrm{l} /$ fish of virulent $A$. hydrophila $\left(10^{6} \mathrm{cfu} / \mathrm{ml}\right)$ on 60 th day post-feeding, while in negative control $\left(\mathrm{C}_{\mathrm{n}}\right)$ group, fish were injected with PBS only. Aeromonas hydrophila was confirmed after re-isolating it from kidney of the fish. The mortality was observed for another 30 days during which diet containing $B$. subtilis was continued in the treatment groups, and at last, survival percentage was calculated.

\section{Haematological parameters}

The total erythrocyte count (TEC) was counted as per Schaperclaus et al. (1991), by mixing $20 \mu \mathrm{l}$ of blood with 3,980 $\mu \mathrm{l}$ of RBC diluting fluid (Hayem's fluid) in a clean glass vial. The mixture was shaken well to suspend the cells uniformly in the solution. The cells were counted using a hemocytometer (Feinoptik, Blakenburg, Germany) and expressed as:

$$
\text { Number of } \mathrm{RBC} / \mathrm{mm}^{3}=N \times 10,000
$$

where $N$ is the total number counted in five squares of the hemocytometer and 10,000 is the factor obtained after taking into consideration the initial dilution factor.

The total leucocyte count (TLC) was counted as per Schaperclaus et al. (1991) by mixing $20 \mu \mathrm{l}$ of blood with 3,980 $\mu \mathrm{l}$ of white blood cell (WBC) diluting fluid (Dacies fluid) in a clean glass vial. The mixture was shaken well to suspend the cells uniformly in the solution. The cells were counted using a hemocytometer (Feinoptik, Blakenburg, Germany) and expressed as: 


\section{Number of $\mathrm{RBC} / \mathrm{mm}^{3}=N \times 500$}

where $N$ denotes the total number of WBCs counted in four squares of the hemocytometer. The factor obtained after taking into consideration the initial dilution was 500 .

For differential leucocyte count (DLC), methanol fixed blood smears were prepared after collecting blood from each group and then stained as per standard procedure using May-Grunwald-Giemsa stain. Leucocytes were counted under microscope through many fields till it reached hundred cells per slide to find out the percentage. Similarly, the percentage of monocytes, granulocytes, and lymphocytes in blood were determined using a blood cell counter.

Blood haemoglobin content was analysed following the Cyanmethemoglobin method using Drabkin's fluid (Qualigens Diagnostic Kit, India). Twenty microlitres of blood was mixed with $5 \mathrm{ml}$ of Drabkin's working solution. The absorbance was measured using a spectrophotometer at wavelength of $540 \mathrm{~nm}$. The haemoglobin content $\left(\mathrm{g} \mathrm{dL}^{-1}\right)$ was calculated as follows.

$$
\frac{\text { Test }}{\text { Standard }} \times \frac{251}{1,000} \times 60
$$

\section{Serum parameters}

The total serum protein (biuret method using buffered dye reagent and biuret reagent, Qualigens diagnostic kit, India) and albumin content (bromocresol green binding method, Qualigens diagnostic kit, India) were analysed in an AR 601, semi-automatic analyser. Similarly, the globulin content (total serum protein - serum albumin) and albuminglobulin ratio were also determined.

Immunological parameters

The respiratory burst activity was done by nitroblue tetrazolium (NBT) assay following the method of Secombes (1990) subsequently modified by (Stasiak and Baumann 1996). Fifty microlitres of blood was placed into the wells of ' $U$ '-bottom microtitre plates and incubated at $37{ }^{\circ} \mathrm{C}$ for $1 \mathrm{~h}$ to facilitate adhesion of cells. Then, the supernatant was removed and the adhered wells were washed three times in PBS (pH 7.2). After washing, $50 \mu$ of $0.2 \%$ NBT was added and resulting solution was incubated for further $1 \mathrm{~h}$. The cells were then fixed with $100 \%$ methanol for 2-3 min and again washed thrice with $30 \%$ methanol. The plates were then air-dried, and $60 \mu \mathrm{l} 2 \mathrm{~N}$ potassium hydroxide and $70 \mu$ limethyl sulphoxide were added into each well to dissolve the formazon blue precipitate formed. The optical density (OD) of the turquoise blue-coloured solution was then read at $540 \mathrm{~nm}$ in an ELISA reader.

The serum bactericidal activity was assayed for bactericidal activity, following Rainger and Rowley (1993). Briefly, overnight-grown A. hydrophila culture was centrifuged and the pellet was washed and suspended in PBS ( $\mathrm{pH} 7.2$ ). The OD of the suspension was adjusted to 0.65 at $540 \mathrm{~nm}$. This bacterial suspension was serially diluted (1:10) with PBS for five times. Serum bactericidal activity was determined by incubating $2 \mu \mathrm{l}$ of the diluted A. hydrophila suspension with $20 \mu \mathrm{l}$ of serum in a microvial for $1 \mathrm{~h}$ at $37^{\circ} \mathrm{C}$. In the control group, PBS was used in place of the serum. After incubation, the number of viable bacteria was determined by counting the colonies grown on nutrient agar plate for $24 \mathrm{~h}$ at $37{ }^{\circ} \mathrm{C}$. 
A turbidimetric assay utilizing lyophilized Micrococcus luteus ATCC 49732 (DIFCO, BBL-Qualis lab) was used to determine lysozyme activity following Sankaran and Gurnani (1972) using hen egg white lysozyme (Hi-media, India) as standard. To a 96-well U-bottom microtitre plates (Tarson, India), $15 \mu \mathrm{l}$ of serum in $150 \mu \mathrm{l}$ of M. luteus suspension [20 $\mathrm{mg}$ of M. luteus suspended in $100 \mathrm{ml}$ acetate buffer $(0.02 \mathrm{M}, \mathrm{pH} 5.5)$ ] was taken. Immediately after adding $M$. luteus suspension, initial OD was taken at $450 \mathrm{~nm}$. After incubating for $1 \mathrm{~h}$ at $25{ }^{\circ} \mathrm{C}$, final OD was taken. Lyophilized hen egg white lysozyme was used to develop a standard curve. Serum lysozyme value is expressed as $\mu \mathrm{g} \mathrm{ml}{ }^{-1}$ equivalent of hen egg white lysozyme activity.

Myeloperoxidase content was measured according to Quade and Roth (1997) with slight modification by Sahoo et al. (2005). About $10 \mu \mathrm{l}$ of serum was diluted with $90 \mu \mathrm{l}$ of Hank's balanced salt solution (HBSS) without $\mathrm{Ca}^{2+}$ or $\mathrm{Mg}^{2+}$ in 96-well plates. Then, $35 \mu \mathrm{l}$

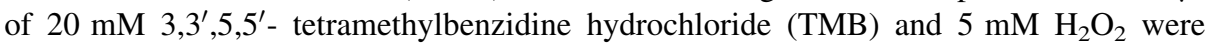
added. The colour change reaction was stopped after 2 min by adding $35 \mu \mathrm{l}$ of $4 \mathrm{M}$ sulphuric acid $\left(\mathrm{H}_{2} \mathrm{SO}_{4}\right)$. The $\mathrm{OD}$ was read at $450 \mathrm{~nm}$ in a microplate reader ( $\mu$ Quant, Universal Microplate Spectrophotometer).

Percentage survival

The percentage survival was calculated as:

Survival $(\%)=($ number of fish survived after challenge/initial number of fish $) \times 100$.

Mortality percentage and relative percentage survival (RPS)

Mortality $(\%)=($ number of fish died after challenge/initial number of fish $) \times 100$

RPS $=1-($ percent mortality in treatment group/percent mortality in control group) $\times 100 \%$

Statistical analysis

Significant differences between treatment groups were tested by one-way analysis of variance (ANOVA), and the comparison of any two mean values was made by Duncan's multiple range tests. A significance level of $P<0.05$ was used. The mean values for preand post-challenge parameters were compared by Student's $t$ test. All the statistical analysis was performed using the software program SPSS (version 15).

\section{Results}

The control fish exhibited sluggish movement with gradual loss of equilibrium and gasped at water surface within $48 \mathrm{~h}$ of challenge. The gross clinical signs observed were petechial haemorrhages, swollen abdomen, reddish vent, and opaque eyes, and during the terminal stages, the animals were seen floating upside down. However, these clinical changes were less evident in B. subtilis-fed group. 
Haematological parameters

The $B$. subtilis feeding affected various haematological parameters during pre- and postchallenge in catla (Table 1). TEC was significantly less $(P<0.05)$ in $\mathrm{T}_{1}$ $\left(1.25 \pm 0.02 \times 10^{6}\right.$ cells $\left./ \mathrm{mm}^{3}\right)$ and $\mathrm{T}_{2}\left(1.26 \pm 0.01 \times 10^{6}\right.$ cells $\left./ \mathrm{mm}^{3}\right)$ groups in comparison with other treatments during pre-challenge. In $\mathrm{T}_{3}$ and $\mathrm{T}_{4}$ groups, no significant difference $(P>0.05)$ in TEC during pre- and post-challenge could be recorded.

TLC did not differ significantly in any of the groups during pre-challenge. However, TLC count was highest in $\mathrm{T}_{2}$ group $\left(3.71 \pm 0.12 \times 10^{3}\right.$ cells $\left./ \mathrm{mm}^{3}\right)$ and least in control $\left(\mathrm{C}_{\mathrm{p}}\right)$ group $\left(3.52 \pm 0.13 \times 10^{3}\right.$ cells $\left./ \mathrm{mm}^{3}\right)$ during pre-challenge. During post-challenge, the TLC in both the control groups was significantly less $(P<0.05)$ in comparison with treatment groups. During the post-challenge, no significant difference $(P>0.05)$ in TLC count could be recorded among the treatment groups, but were significantly different $(P<0.05)$ with regard to individual treatment in comparison with pre-challenge.

Haemoglobin content in treatment groups increased, but not at significant level in comparison with control groups during pre-challenge. On the contrary, haemoglobin content decreased significantly $\left[(P<0.05)\right.$ in the control $\left(\mathrm{C}_{\mathrm{p}}\right)$ group] during post-challenge. The haemoglobin content also decreased in all treatment groups during post-challenge, but not at significant level $(P<0.05)$ except in $\mathrm{T}_{1}$.

The effect of probiotic treatment on the DLC percentage is shown in Table 2. No significant change $(P>0.05)$ in the granulocytes $(\%)$ could be recorded in any of the groups during pre-challenge, but their percentage significantly increased in $T_{2}, T_{3}$, and $T_{4}$ treatment groups during post-challenge. Similarly, granulocytes $(\%)$ significantly increased during post-challenge in comparison with pre-challenge in all treatment groups. On the other hand, lymphocytes (\%) significantly increased in all treatments during pre-challenge, but decreased during post-challenge among the treatment groups. Moreover, their percentage was also significantly low during post-challenge in comparison with pre-challenge. However, significant difference could be recorded in $\mathrm{C}_{\mathrm{p}}$ and $\mathrm{T}_{2}$ during post-challenge in comparison with pre-challenge.

\section{Serum parameters}

Effect of probiotic treatment on serum parameters of $C$. catla during pre- and post-challenge is presented in Table 3 . Total serum protein increased significantly $(P<0.05)$ in all treatment groups in comparison with control groups during pre-challenge. Among the treatment groups, increased level was recorded in $\mathrm{T}_{3}$ and $\mathrm{T}_{4}$ as compared to other groups. However, in all treatment groups, total serum protein content decreased during postchallenge, but the level was significantly high in comparison with $\mathrm{C}_{\mathrm{p}}$. The lowest protein content was observed in the control $\left(\mathrm{C}_{\mathrm{p}}\right)$ group during post-challenge. Treatment groups did not show significant reduction $(P<0.05)$ in total serum protein during post-challenge in comparison with pre-challenge. Albumin content increased significantly $(P<0.05)$ in treatment groups in comparison with control groups during pre-challenge.

The globulin content of $C$. catla increased gradually as the probiotic concentration increased in feed during pre-challenge. The globulin level was significantly high in $T_{3}$ group $(1.68 \pm 0.04 \mathrm{gm} / \mathrm{dl})$ during pre-challenge. However, the globulin level decreased in all groups, but was not at a significant level $(P>0.05)$ after post-challenge. There was no significant difference $(P>0.05)$ in globulin content between pre- and post-challenge in all treatment groups. The $\mathrm{A} / \mathrm{G}$ ratio in $C$. catla did not vary significantly in any groups during pre-challenge, but lowest content was found in $\mathrm{T}_{3}(1.30 \pm 0.01)$. A/G ratio was 
Table 1 Effect of Bacillus subtilis on various haematological parameters of Catla catla fingerlings during pre- and post-challenge with Aeromonas hydrophila

\begin{tabular}{|c|c|c|c|c|c|c|}
\hline \multirow[t]{2}{*}{ Treatments } & \multicolumn{2}{|c|}{ TEC $\left(\times 10^{6}\right.$ cells $\left./ \mathrm{mm}^{3}\right)$} & \multicolumn{2}{|c|}{ TLC $\left(\times 10^{4}\right.$ cells $\left./ \mathrm{mm}^{3}\right)$} & \multicolumn{2}{|l|}{$\mathrm{Hb}(\mathrm{g} \%)$} \\
\hline & $\begin{array}{l}\text { Pre- } \\
\text { challenge }\end{array}$ & $\begin{array}{l}\text { Post- } \\
\text { challenge }\end{array}$ & $\begin{array}{l}\text { Pre- } \\
\text { challenge }\end{array}$ & $\begin{array}{l}\text { Post- } \\
\text { challenge }\end{array}$ & $\begin{array}{l}\text { Pre- } \\
\text { challenge }\end{array}$ & $\begin{array}{l}\text { Post- } \\
\text { challenge }\end{array}$ \\
\hline$C_{P}$ & $1.20^{\mathrm{cA}} \pm 0.01$ & $0.82^{\mathrm{cB}} \pm 0.03$ & $3.52 \pm 0.13$ & $3.68^{b} \pm 0.22$ & $6.80^{\mathrm{A}} \pm 0.35$ & $5.20^{\mathrm{cB}} \pm 0.12$ \\
\hline$C_{N}$ & $1.20^{\mathrm{c}} \pm 0.01$ & $1.18^{\mathrm{ab}} \pm .05$ & $3.53 \pm 0.13$ & $3.55^{\mathrm{b}} \pm 0.14$ & $6.83 \pm 0.34$ & $6.90^{\mathrm{a}} \pm 0.17$ \\
\hline $\mathrm{T}_{1}$ & $1.25^{\mathrm{bA}} \pm 0.02$ & $1.02^{\mathrm{bB}} \pm 0.07$ & $3.45^{\mathrm{A}} \pm 0.20$ & $4.41^{\mathrm{aB}} \pm 0.24$ & $7.11^{\mathrm{A}} \pm 0.23$ & $6.39^{\mathrm{bB}} \pm 0.17$ \\
\hline $\mathrm{T}_{2}$ & $1.26^{\mathrm{bA}} \pm 0.01$ & $1.13^{\mathrm{abB}} \pm 0.05$ & $3.71^{\mathrm{A}} \pm 0.12$ & $4.45^{\mathrm{aB}} \pm 0.20$ & $7.25^{\mathrm{A}} \pm 0.20$ & $7.02^{\mathrm{aB}} \pm 0.13$ \\
\hline $\mathrm{T}_{3}$ & $1.29^{\mathrm{a}} \pm 0.01$ & $1.25^{\mathrm{a}} \pm .06$ & $3.69^{\mathrm{A}} \pm 0.19$ & $4.49^{\mathrm{aB}} \pm 0.17$ & $7.41^{\mathrm{A}} \pm 0.24$ & $7.11^{\mathrm{aB}} \pm 0.18$ \\
\hline $\mathrm{T}_{4}$ & $1.30^{\mathrm{a}} \pm 0.02$ & $1.19^{\mathrm{ab}} \pm .05$ & $3.57^{\mathrm{A}} \pm 0.16$ & $4.51^{\mathrm{aB}} \pm 0.29$ & $7.43^{\mathrm{A}} \pm 0.25$ & $7.15^{\mathrm{aB}} \pm .09$ \\
\hline
\end{tabular}

Mean values in rows bearing different superscript (upper case) and column bearing different superscript (lower case) vary significantly $(P<0.05)$ with respect to individual parameter. TEC $\left(\times 10^{6} \mathrm{cells} / \mathrm{mm}^{3}\right)$, total erythrocyte count in millions of cells per cubic millimetre; TLC $\left(\times 10^{4}\right.$ cells $\left./ \mathrm{mm}^{3}\right)$, total leucocyte count in $10^{4}$ number of cells per cubic millimetre; $\mathrm{Hb}(\mathrm{g} \%)$, haemoglobin content in gram \%

significantly high $(P<0.05)$ in the control $\left(\mathrm{C}_{\mathrm{p}}\right)$ group $(1.70 \pm 0.04)$ in comparison with treatment groups during post-challenge.

\section{Immunological parameters}

The respiratory burst activity in various treatment groups during pre- and post-challenge is given in Table 4 . The respiratory burst activity increased significantly as the concentration of probiotic in treatment groups increased during pre-challenge and also maintained at high level during post-challenge. Treatment groups $\left(\mathrm{T}_{2}, \mathrm{~T}_{3}\right.$, and $\left.\mathrm{T}_{4}\right)$ showed significantly high $(P<0.05)$ respiratory burst activity in comparison with control groups during pre-challenge. The mean $( \pm \mathrm{SD})$ OD value was highest in $\mathrm{T}_{4}$ group $(0.41 \pm 0.01)$ during prechallenge and also maintained at high level $(0.59 \pm 0.02)$ during post-challenge.

Serum lysozyme activity was significantly high $(P<0.05)$ in all probiotic treatment groups in comparison with the control $\left(\mathrm{C}_{\mathrm{p}}\right)$ group during pre- and post-challenge (Table 3$)$. The serum lysozyme content was highest in $\mathrm{T}_{3}$ and $\mathrm{T}_{4}$ groups with no significant difference $(P>0.05)$ between these two groups during pre- and post-challenge. However, significant rise $(P<0.05)$ in serum lysozyme content in treatment groups was recorded during postchallenge in comparison with pre-challenge.

Myeloperoxidase activity was significantly high $(P<0.05)$ in treatment groups in comparison with the control $\left(\mathrm{C}_{\mathrm{p}}\right)$ group during both pre- and post-challenge (Table 3$)$. Among the treatment groups, least myeloperoxidase activity with a mean $( \pm \mathrm{SD})$ OD of $0.070( \pm 0.00)$ was recorded in $\mathrm{T}_{1}$ group and highest in $\mathrm{T}_{4}$ group with a mean $( \pm \mathrm{SD}) \mathrm{OD}$ of $0.123( \pm 0.01)$ during pre-challenge. However, myeloperoxidase activity was significantly high $(P<0.05)$ in $\mathrm{T}_{3}$ and $\mathrm{T}_{4}$ groups during pre-challenge. Similar type of trend was also recorded during post-challenge as well. However, significant rise in the myeloperoxidase activity in treatment groups was recorded during post-challenge in comparison with prechallenge.

Serum bactericidal activity as assessed by the reduction in viable count of $A$. hydrophila was significantly less $(P<0.05)$ in all treatment groups in comparison with control groups during pre-challenge (Table 5). No significant difference in the reduction in viable count could be recorded during pre-challenge in treatment groups. However, in $\mathrm{T}_{3}$ group, least 


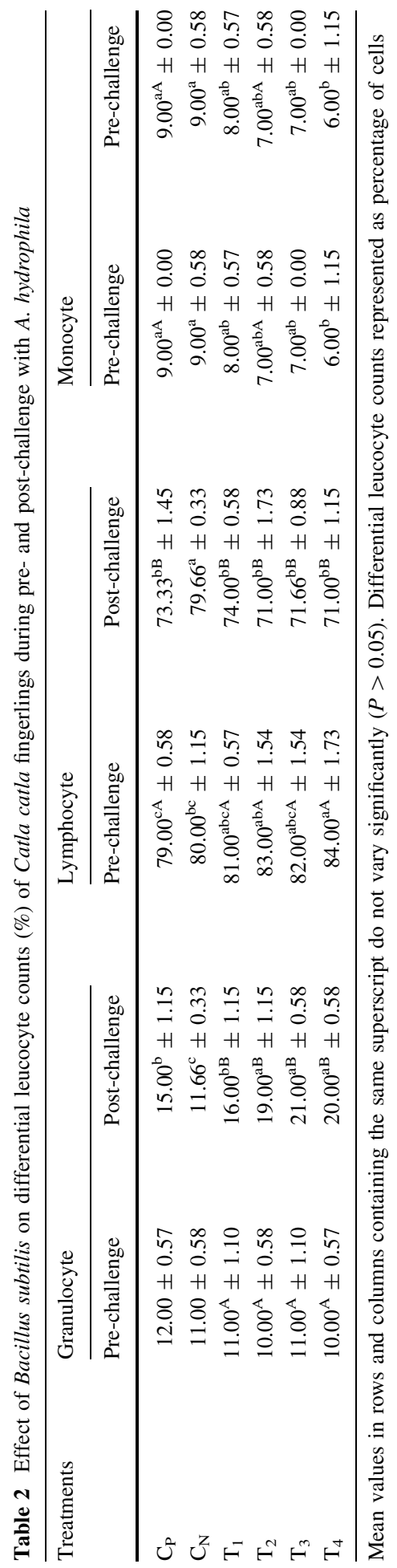




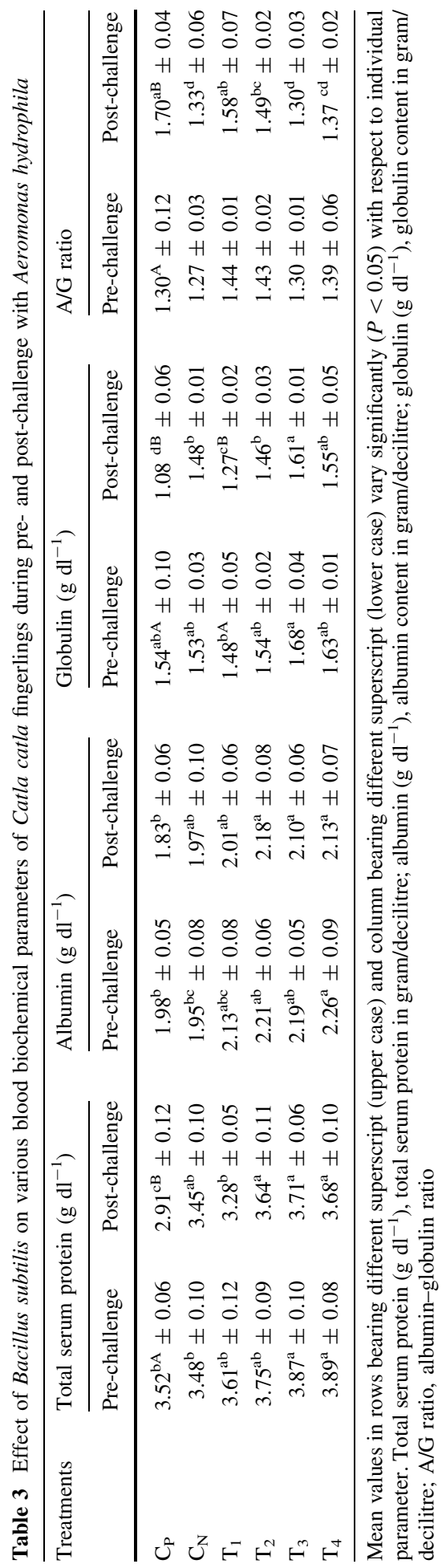




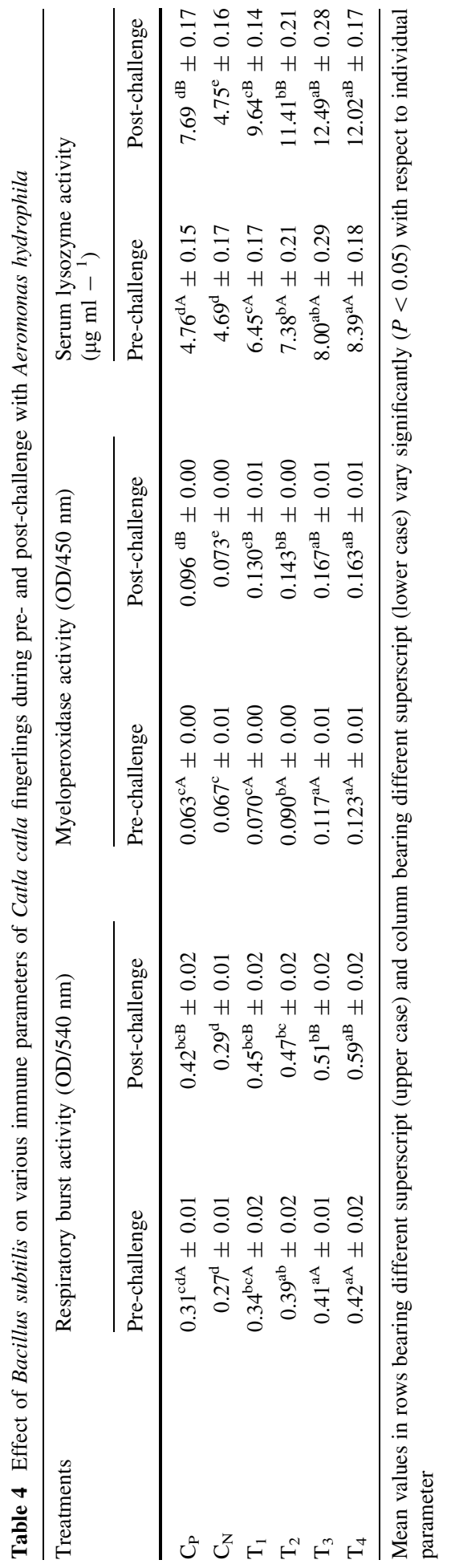


A. hydrophila count $(247 \pm 11.54 \mathrm{cfu} / \mathrm{ml})$ was recorded during pre-challenge. Similarly, serum bactericidal activity was also highest in $\mathrm{T}_{3}$ with a viable $A$. hydrophila count of 201 $( \pm 7.50) \mathrm{cfu} / \mathrm{ml}$, while least count was recorded in the control $\left(\mathrm{C}_{\mathrm{n}}\right)$ group $(428 \pm 16.16 \mathrm{cfu} /$ $\mathrm{ml})$ during post-challenge. However, significant difference $(P<0.05)$ in serum bactericidal activity was recorded only in $\mathrm{C}_{\mathrm{p}}$ and $\mathrm{T}_{3}$ group during post-challenge in comparison with pre-challenge.

\section{Percentage survival}

On challenge with virulent $A$. hydrophila, survivability percentage was least in $\mathrm{C}_{\mathrm{p}}$ $(37.78 \pm 3.33 \%)$. However, among treatment groups, the survivability was found to be directly related to the concentration of the probiotic (Fig. 1) and the survival percentage was highest in $\mathrm{T}_{4}$ group $(86.67 \pm 6.67 \%)$, while least in $\mathrm{T}_{1}$ group $(66.67 \pm 6.67 \%)$.

Mortality percentage and relative percentage survival (RPS)

The mortality percentage was highest in $\mathrm{C}_{\mathrm{p}}(62.22 \%)$. However, among treatment groups, the mortality was found to be inversely related to the concentration of the probiotic (Fig. 2) and the mortality percentage was lowest in $\mathrm{T}_{4}$ group $(13.33 \pm 3.85 \%)$, while in $\mathrm{T}_{1}$ group, it was $33.33 \pm 3.85 \%$. The RPS was highest in $\mathrm{T}_{4}$ group $(78.95 \%)$, while least in $\mathrm{T}_{1}$ $(47.37 \%)$.

\section{Discussion}

There is a growing interest for probiotics to be used in aquaculture as alternative preventive strategies (Nayak 2010). However, one of the main challenges in developing probiotic bacteria is using appropriate selection of strains based on scientific data. The present investigation was in the same direction, and therefore, an effort has been made to provide an insight into how probiotic $B$. subtilis helps in preventing the diseases through immunohaematological studies during pre- and post-challenge.

During pre-challenge, the total erythrocyte counts (TEC) increased significantly due to supplementation of $B$. subtilis in the feed, which is an indication of improved health condition of the catla. The increase in TEC and haemoglobin content following B. subtilis feeding in Labeo rohita was also reported earlier (Kumar et al. 2006). Furthermore, the

Table 5 Effect of Bacillus subtilis on serum bactericidal activity (total bacterial count) of Catla catla fingerlings during pre- and post-challenge with Aeromonas hydrophila

\begin{tabular}{lrc}
\hline Treatments & Pre-challenge & Post-challenge \\
\hline $\mathrm{C}_{\mathrm{P}}$ & $451^{\mathrm{aA}} \pm 29.44$ & $345^{\mathrm{bB}} \pm 20.61$ \\
$\mathrm{C}_{\mathrm{N}}$ & $435^{\mathrm{a}} \pm 20.20$ & $428^{\mathrm{a}} \pm 16.16$ \\
$\mathrm{~T}_{1}$ & $315^{\mathrm{b}} \pm 17.32$ & $294^{\mathrm{b}} \pm 17.32$ \\
$\mathrm{~T}_{2}$ & $273^{\mathrm{b}} \pm 17.32$ & $252^{\mathrm{bc}} \pm 9.81$ \\
$\mathrm{~T}_{3}$ & $247^{\mathrm{bA}} \pm 11.54$ & $201^{\mathrm{eB}} \pm 7.50$ \\
$\mathrm{~T}_{4}$ & $254^{\mathrm{b}} \pm 14.43$ & $217^{\mathrm{de}} \pm 9.81$ \\
\hline
\end{tabular}

Mean values in rows bearing different superscript (upper case) and column bearing different superscript (lower case) vary significantly $(\mathrm{P}<0.05)$ 
reduction in $\mathrm{RBC}$ count after challenge is probably attributed to the ability of the pathogen to haemolyse erythrocytes (Olivier et al. 1981). Earlier, Ikeda et al. (1976) also reported decrease in the erythrocytes count and the haemoglobin content in Yellow tail, Seriola quinquiradiata challenged with Nocardia kampachi. In our study, similar type of reduction in erythrocytes count was recorded in control group $\left(\mathrm{C}_{\mathrm{p}}\right)$; however, minimal reduction was recorded in the probiotic-fed groups $\left(\mathrm{T}_{3}\right.$ and $\left.\mathrm{T}_{4}\right)$ after post-challenge. The haemoglobin content showed almost similar trend as TEC. The adequate production of erythrocytes resulted in optimum maintenance of increased haemoglobin content. This indicates that the involvement of B. subtilis in the improvement of blood parameters of catla which in turn helped in minimizing the adverse effect of A. hydrophila.

Xie et al. (1993) in a study reported that under normal condition, the amount of white blood cells of common carp (C. carpio) was $0.5 \%$ of the amount of red blood cells. However, in case of the infected carp, the white blood cells increased up to $16.25 \%$ (an increase of 31.86 times). The increase in leucocytes probably represents the inflammatory response against the bacteria (Roberts 1989). In the present study, TLC increased in fishes fed feed containing $B$. subtilis with respect to the fishes fed feed without $B$. subtilis. In a previous study, it was also reported that supplementation with B. subtilis could increase TLC in L. rohita (Kumar et al. 2006). Recently, Kamgar and Ghane (2012) also recorded significant increase in leucocyte count in rainbow trout, Oncorhynchus mykiss fed with $B$. subtilis when challenged with Streptococcus iniae. The result from present experiment also revealed an increase in TLC in treatment groups $\left(\mathrm{T}_{1}, \mathrm{~T}_{2}, \mathrm{~T}_{3}\right.$, and $\left.\mathrm{T}_{4}\right)$ compared with both the control $\left(C_{p}\right.$ and $\left.C_{n}\right)$ groups. This revealed the heightened immune response in the fish which was fed with feed containing B. subtilis. This could probably prove the immunostimulatory effect of $B$. subtilis.

The increase in granulocyte and monocytes revealed that the non-specific immune system is activated during the post-challenge period. Carassius auratus following intramuscular injection of Aeromonas hydrophila exhibited a decrease in lymphocyte and an increase in granulocyte count for the first $36 \mathrm{~h}$ post-infection (Brenden and Huizinga 1986). In the present study, however, there was an increase in granulocyte and monocyte counts in treatment groups $\left(\mathrm{T}_{1}, \mathrm{~T}_{2}, \mathrm{~T}_{3}\right.$, and $\left.\mathrm{T}_{4}\right)$ and decreased lymphocyte count in the same compared with the control group. The increase in neutrophil in the present study was due to the enhanced innate immune response in catla fed with $B$. subtilis.

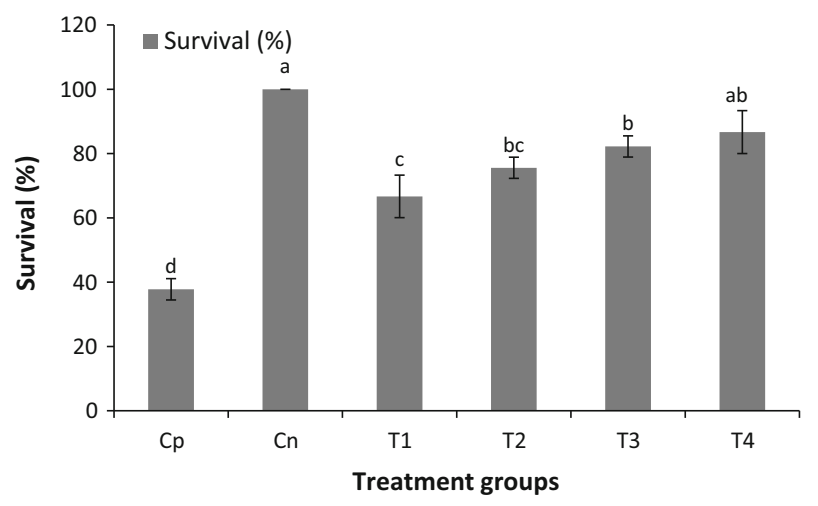

Fig. 1 Effect of Bacillus subtilis on the percentage survival of Catla catla after the challenge with Aeromonas hydrophila. Mean values bearing different superscript vary significantly $(P<0.05)$ 


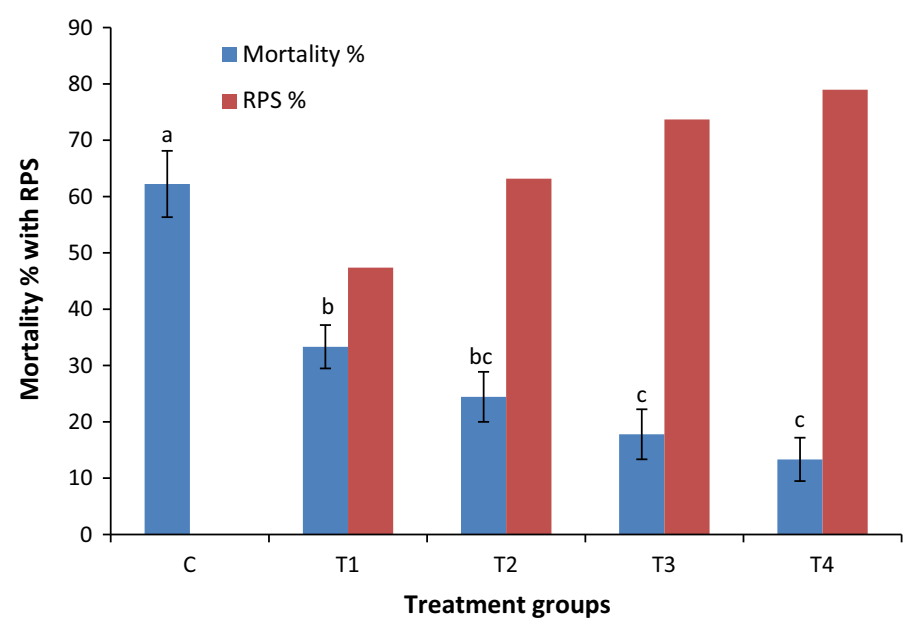

Fig. 2 Effect of Bacillus subtilis on the mortality percentage and relative percentage survival (RPS) of Catla catla after the challenge with Aeromonas hydrophila. Mean values bearing different superscript vary significantly $(P<0.05)$

Among the serum proteins, albumin and globulin are the major proteins which play a significant role in the immune response. Globulins like gamma globulin are absolutely essential for maintaining a healthy immune system and contain all the immunoglobulin in the blood. In the present study, total serum protein, albumin, and globulin content had increased in the treatment groups during pre-challenge, which indicated the enhancement of innate immunity of the experimental fish. The increased total protein and globulin in rohu, L. rohita by B. subtilis was also reported earlier (Kumar et al. 2006). Increase in the serum protein, albumin, and globulin levels is believed to be associated with a stronger innate response in fishes (Wiegertjes et al. 1996). In the present study, during post-challenge the decline in total protein and albumin content has been observed, but globulin level was in increasing trend. After challenge study, reduction in serum protein might have been due to leaking because of increased vascular permeability (Green et al. 1999; Ellis et al. 1981) along with impaired synthesis and non-specific proteolysis of serum protein (Ellis et al. 1981). The significant decrease in the $A / G$ ratio in treatment groups $T_{2}$ and $T_{3}$ compared with control during the pre-challenge indicated enhancement in non-specific immunity.

Different probiotics are often reported to stimulate piscine immune system (Nayak 2010). Dietary supplementation of B. subtilis often improves the growth and nutrition, immunohaematological responses, and disease resistance in different fish species (Nayak et al. 2007; Aly et al. 2008; Kamgar and Ghane 2012; Liu et al. 2012; Purwandari and Chen 2013), and the findings of the present study corroborated to these earlier studies. Here in this study, apart from different haematological parameters B. subtilis treatment was also found to affect various immunological parameters of catla during pre- and post-challenge. Probiotic like B. subtilis is rich source of many biologically active substances that can potentially trigger various biological systems including the immune system (both innate and adaptive immunity) which in turn may contribute to good health and disease resistance of host.

In the present study, an increase in respiratory burst activity was observed in all probiotic treatment groups $\left(\mathrm{T}_{1}, \mathrm{~T}_{2}, \mathrm{~T}_{3}\right.$, and $\left.\mathrm{T}_{4}\right)$ during both pre- and post-challenge. These 
observations are similar to the findings of Kumar et al. (2008) in L. rohita who supplemented B. subtilis by oral route.

Lysozyme occurs prominently in fish serum and mucus (Ellis 1999) with more bactericidal activity in comparison with that of higher vertebrates (Ellis 2001) and considered to be a natural protective mechanism in fish (Ingram 1980). Fish lysozymes are thought to be present in two forms: lysozyme C and lysozyme G (Wei et al. 2014). Lysozyme C and its variant have been cloned in rainbow trout (Dautiny et al. 1991; Savana et al. 2003), carps (Savana et al. 2002; Fujiki et al. 2000), and Japanese flounder (Hikima et al. 1997). Only one G-type lysozyme has been identified in Japanese flounder, Large yellow croaker, Atlantic cod, Common carp, Grass carp, and Orangespotted grouper (Hikima et al. 2001; Zheng et al. 2007; Larsen et al. 2009; Savana et al. 2003; Ye et al. 2010; Wei et al. 2014). Paulsen et al. (2001) reported enhanced lysozyme production in Atlantic salmon (Salmo salar L.) macrophages treated with yeast betaglucan and bacterial lipopolysaccharide. During this study, its level increased significantly after administration of B. subtilis in the diet during pre- and post-challenge. The highest serum lysozyme activity in catla was recorded in $\mathrm{T}_{3}$ group both during pre- and post-challenge. The significant increase in the lysozyme activity of the B. subtilis-fed groups suggests the involvement of this probiont in the piscine immune system. Mock and Peters (1990) reported an initial activation of lysozyme activity followed by impairment and final breakdown of this response with respect to stress. In the present study, an increase in serum lysozyme activity was observed in treatment groups $\mathrm{T}_{2}, \mathrm{~T}_{3}$, and $\mathrm{T}_{4}$ groups during post-challenge as well.

Myeloperoxidase is a haemoprotein secreted during activation of neutrophils, which plays an important role in the defence of the organism. Myeloperoxidase is stored in primary, azurophilic granules of neutrophils. It is a major component of the broad bactericidal armamentarium of neutrophils. It utilizes hydrogen peroxide during respiratory burst to produce hypochlorous acid (Dalmo et al. 1997). In the present study, the treatment groups $\left(\mathrm{T}_{1}, \mathrm{~T}_{2}, \mathrm{~T}_{3}\right.$, and $\left.\mathrm{T}_{4}\right)$ showed higher activity during pre- and post-challenge.

Nevertheless, serum bactericidal activity increased in all the treatment $\left(T_{1}, T_{2}, T_{3}\right.$, and $\mathrm{T}_{4}$ ) groups. In the previous study, we had also demonstrated increased serum bactericidal effect of B. subtilis in L. rohita (Kumar et al. 2008). The higher bactericidal activities can possibly be due to higher activity of lysosomal enzymes. Similar views were also put forth by Nikoskelainess et al. (2003) who observed significant increase in complement bactericidal activity of rainbow trout fed with Lactobacillus rhamnosus. All these enhanced parameters during probiotic feeding not only helped in immune stimulation, but also believed to be responsible for protecting catla from challenge with A. hydrophila. In the present study, the decreased mortality percentage was recorded in fishes fed with $B$. subtilis. On the contrary, He et al. (2011) documented beneficial effects on growth, upregulation of cytokines expression in liver, and modulating intestinal microbiota community in koi carp, Cyprinus carpio by dietary supplementation of B. subtilis C-3102, but failed to record any significant protection against $A$. hydrophila challenge. Such differences might be attributed to the possible strain differences among the used strains of a specific probiotic species and also the host species.

In conclusion, dietary administration of $B$. subtilis could improve both the haematological and immunological responses. Therefore, looking into the concern regarding the use of antibiotics and other chemotherapeutics, probiotic like B. subtilis could be an ideal substitute for control of diseases in Indian major carp culture. 
Acknowledgments The authors are grateful to the University Grant Commission, New Delhi, for awarding the first author with CSIR-UGC Junior Research Fellowship and Director, and to Central Institute of Fisheries Education, Mumbai, for providing the facilities to carry out the research work.

\section{References}

Aly SM, Abdel-Galil AY, Abdel-Aziz GA, Mohamed MF (2008) Studies on Bacillus subtilis and Lactobacillus acidophilus, as potential probiotics, on the immune response and resistance of Tilapia nilotica (Oreochromis niloticus) to challenge infections. Fish Shellfish Immunol 25:128-136

Bagheri T, Hedayati SA, Yavari V, Alizade M, Farzanfar A (2008) Growth, survival and gut microbial load of rainbow trout (Onchorhynchus mykiss) fry given diet supplemented with probiotic during the two months of first feeding. Turk J Fish Aqua Sci 8:43-48

Brenden RA, Huizinga HW (1986) Pathophysiology of experimental Aeromonas hydrophila infection in goldfish, Carassius auratus (L.). J Fish Dis 9:163-167

Dalmo RA, Ingebrigtsen K, Bøgwald J (1997) Non-specific defence mechanisms in fish, with particular reference to the reticuloendothelial system (RES). J Fish Dis 20:241-273

Dautiny A, Prager EM, Pham-Dhin D, Jolles J, Pakdel F, Grinde B (1991) cDNA and amino acid sequences of rainbow trout (Oncorhynchus mykiss) lysozymes and their implications for the evolution of lysozyme and lactalbumin. J Mol Evol 32:187-198

Díaz-Rosales P, Arijo S, Chabrillón M, Alarcón FJ, Tapia-Paniagua ST, Martínez-Manzanares E, Balebona MC, Morinigo MA (2009) Effects of two closely related probiotics on respiratory burst activity of Senegalese sole (Solea senegalensis, Kaup) phagocytes, and protection against Photobacterium damselae subsp. piscicida. Aquaculture 293:16-21

Dimitroglou A, Merrifield DL, Carnevali O, Picchietti S, Avella M, Daniels C, Guroy D, Davies SJ (2011) Microbial manipulations to improve fish health and production: mediterranean perspective. Fish Shellfish Immunol 30:1-16

EL-Dakar AY, Shalaby SM, Saoud IP (2007) Assessing the use of a dietary probiotic/prebiotic as an enhancer of spinefoot rabbit fish Siganus rivulatus survival and growth. Aquac Nutr 13:407-412

Ellis AE (1999) Immunity to bacteria in fish. Fish Shellfish Immunol 9:291-308

Ellis AE (2001) Innate host defense mechanisms of fish against viruses and bacteria. Dev Comp Immunol 25:827-839

Ellis AE, Hastings TS, Munro ALS (1981) The role of Aeromonas salmonicida extracellular products in the pathology of furunculosis. J Fish Dis 4:41-51

FAO (2006) Cultured aquatic species information programme. Catla catla (Hamilton 1822), pp1-11

Fujiki K, Shin D, Nakao M, Yano T (2000) Molecular cloning of carp (Cyprinus carpio) leucocyte cellderived chemotaxin 2, glia maturation factor, CD45 and lysozyme C by use of suppression subtractive hybridization. Fish Shellfish Immunol 10:643-650

Green DH, Wakeley PR, Page A, Barnes A, Baccigalupi L, Ricca E, Cutting SM (1999) Characterization of two Bacillus probiotics. Appl Environ Microbiol 65:4288-4291

He S, Liu W, Zhou Z, Mao W, Ren P, Marubashi T, Ringo E (2011) Evaluation of probiotic strain Bacillus subtilis C-3102 as a feed supplement for koi carp (Cyprinus carpio). J Aquac Res Dev 1:005

Hikima J, Hirono T, Aoki T (1997) Characterization and expression of C-type lysozyme cDNA from Japanese flounder (Paralichthys olivaceus). Mol Mar Biol Biotechnol 6:339-344

Hikima J, Minagawa S, Hirono I, Aoki T (2001) Molecular cloning, expression and evolution of Japanese flounder goose-type lysozyme gene, and lytic activity of its recombinant protein. Biochim Biophys Acta 1520:35-44

Ikeda Y, Ozaki H, Hayama K, Ikeda S, Minami T (1976) Diagnostic study on blood constituents in the yellow tail inoculated with Nocardia kampachi. Bull Jap Soc Sci Fish 42:1055-1064

Ingram GA (1980) Substances involved in the natural resistance of fish to infection-a review. J Fish Biol $16: 23-60$

Irianto A, Austin B (2002) Use of probiotics to control furunculosis in rainbow trout, Oncorhynchus mykiss (Walbaum). J Fish Dis 25:333-342

Kamgar M, Ghane M (2012) Evaluation of Bacillus subtilis effect as probiotic on hematological parameters of rainbow trout, Oncorhynchus mykiss (Walbaum) following experimental infection with Streptococcus iniae. J Fish Aquat Sci 7:1-9

Kim JY, Kwon JH, Ahn SH, Lee SI, Han YS, Choi YO, Lee SY, Ahn KM, Ji GE (2010) Effect of probiotic mix (Bifidobacterium bifidum, Bifidobacterium lactis, Lactobacillus acidophilus) in the primary 
prevention of eczema: a double-blind, randomized, placebo-controlled trial. Pediatr Allery Immunol 21:386-393

Kumar R, Mukherjee SC, Prasad KP, Pal AK (2006) Evaluation of Bacillus subtilis as a probiotic to Indian major carp Labeo rohita (Ham.). Aquac Res 37:1215-1221

Kumar R, Mukherjee SC, Ranjan R, Nayak SK (2008) Enhanced innate immune parameters in Labeo rohita (Ham.) following oral administration of Bacillus subtilis. Fish Shellfish Immunol 24:168-172

Larsen AN, Solstad T, Svineng G, Seppola M, Jørgensen TØ (2009) Molecular characterization of a goosetype lysozyme gene in Atlantic cod (Gadus morhua L.). Fish Shellfish Immunol 26:122-132

Liu CH, Chiu CH, Wang SW, Cheng W (2012) Dietary administration of the probiotic, Bacillus subtilis E20, enhances the growth, innate immune responses, and disease resistance of the grouper, Epinephelus coioides. Fish Shellfish Immunol 33:699-706

Merrifield DL, Dimitroglou A, Bradley G, Baker RTM, Davies SJ (2010a) Probiotic applications for rainbow trout (Oncorhynchus mykiss Walbaum I). Effects on growth performance, feed utilization, intestinal microbiota and related health criteria. Aquac Nutr 16:504-510

Merrifield DL, Dimitroglou A, Foey A, Davies SJ, Baker R, Bøgwald J, Castex M, Ringo E (2010b) The current status and future focus of probiotic and prebiotic applications for salmonids. Aquaculture 302:1-18

Mock A, Peters G (1990) Lysozyme activity in rainbow trout, Oncorhynchus mykiss (Walbaum), stressed by handling, transport and water pollution. J Fish Biol 37:873-885

Nayak SK (2010) Probiotics and immunity: a fish perspective. Fish Shellfish Immunol 29:2-14

Nayak SK, Swain P, Mukherjee SC (2007) Effect of dietary supplementation of probiotic and vitamin C on the immune response of Indian major carp, Labeo rohita (Ham). Fish Shellfish Immunol 23:892-896

Nikoskelainen S, Ouwehand AC, Bylund G, Salminen S, Lilius EM (2003) Immune enhancement in rainbow trout (Oncorhynchus mykiss) by potential probiotic bacteria (Lactobacillus rhamnosus). Fish Shellfish Immunol 15:443-452

Olivier G, Lallier R, Lariviere S (1981) A toxigenic profile of Aeromonas hydrophila and Aeromonas sobria isolated from fish. Can J Microbiol 27:330-333

Paulsen SM, Engstad RE, Robertsen B (2001) Enhanced lysozyme production in Atlantic salmon (Salmo salar L.) macrophages treated with yeast B-glucan and bacterial lipopolysaccharide. Fish Shellfish Immunol 11:23-37

Purwandari AR, Chen HY (2013) Effects of probiotic Bacillus subtilis on intestinal microbial diversity and immunity of orange spotted grouper Epinephelus coioides. J Appl Biotechnol 1:25-36

Qi Z, Zhang XH, Boon N, Bossier P (2009) Probiotics in aquaculture of China-current state, problems and prospect. Aquaculture 290:15-21

Quade MJ, Roth JA (1997) A rapid, direct assay to measure degranulation of bovine neutrophil primary granules. Vet Immunol Immunopathol 58:239-248

Rainger GE, Rowley AF (1993) Antibacterial activity in the serum and mucus of rainbow trout, Oncorhynchus mykiss, following immunization with Aeromonas salmonicida. Fish Shellfish Immunol 3:475-482

Ranjan R, Prasad KP, Vani T, Kumar R (2012) Effect of dietary chitosan on haematology, innate immunity and disease resistance of Asian seabass Lates calcarifer (Bloch). Aquac Res 45(6):983-993

Roberts RJ (1989) Nutritional pathology of teleosts. In: Roberts RJ (ed) Fish pathology. Bailliere Tindall, London, pp 337-362

Sahoo PK, Kumari J, Mishra BK (2005) Non-specific immune responses in juveniles of Indian major carps. J Appl Ichthyol 21:151-155

Salinas I, Cuesta A, Esteban MA, Meseguer J (2005) Dietary administration of Lactobacillus delbrueckii and Bacillus subtilis, single or combined, on gilthead seabream cellular innate immune responses. Fish Shellfish Immunol 19:67-77

Sankaran K, Gurnani S (1972) On the variation in the catalytic activity of lysozyme in fishes. Indian J Biochem Biophys 9:62-165

Savan R, Sakai M (2002) Analysis of expressed sequence tags (EST) obtained from common carp Cyprinus carpio $\mathrm{L}$ head kidney cells after stimulation by two mitogens, lipopolysaccharide and concanavalin-A. Comp Biochem Physiol Part B Biochem Mol Biol 131:71-82

Savan R, Amanb A, Sakaib M (2003) Molecular cloning of G type lysozyme cDNA in common carp (Cyprinus carpio L.). Fish Shellfish Immunol 15:263-268

Schaperclaus W, Kulow H, Schreckenbach K (1991) Haematological and serological technique. Fish Dis $1: 71-108$

Secombes CJ (1990) Isolation of salmonid macrophages and analysis of their killing activity. In: Stolen JS, Feltcher TC, Anderson DP, Robertson BS, Van Muiswinkel WB (eds) Techniques in fish immunology. SOS Publication, Fair Haven, pp 137-154 
Stasiak SA, Baumann PC (1996) Neutrophil activity as a potential bioindicator for contaminant analysis. Fish Shellfish Immunol 6:537-539

Wei S, Huang Y, Huang X, Cai J, Wei J, Li P, Qin Q (2014) Molecular cloning and characterization of a new G-type lysozyme gene (Ec-lysG) in orange-spotted grouper, Epinephelus coioides. Dev Comp Immunol 46:401-412

Weissmann G (2010) It's complicated: inflammation from Metchnikoff to Meryl Streep. FASEB J $24: 4129-4132$

Wiegertjes GF, Bongers AB, Voorthuis P, Zandieh DB, Groeneveld A, Muiswinkel WB, Stet RJM (1996) Characterization of isogenic carp (Cyprinus carpio L.) lines with a genetically determined high or low antibody production. Anim Genet 27:313-319

Wimalawickrama ND, Pathiratne A (2005) Evaluation of the effects of infestation by trematodes and copepodes on Catla catla an Indian carp cultured in Sri Lanka. Sri Lanka J Aquat Sci 10:85-96

Xie Y, Liu D, Zou J, Li G, Zhu Z (1993) Gene transfer via electroporation in fish. Aquaculture 111:207-213

Ye X, Zhang L, Tian Y, Tan A, Bai J, Li S (2010) Identification and expression analysis of the g-type and c-type lysozymes in grass carp Ctenopharyngodon idella. Dev Comp Immunol 34:501-509

Zheng W, Tian C, Chen X (2007) Molecular characterization of goose-type lysozyme homologue of large yellow croaker and its involvement in immune response induced by trivalent bacterial vaccine as an acute-phase protein. Immunol Lett 113:107-116 